\title{
Spring Waters as an Indicator for Non-Point-Source Nitrate Pollution of Rural Watercourses - Findings from Two Decades of Spring Monitoring in the Low Mountain Landscape of Saarland
}

\section{Gero Weber ( $\sim$ gero.weber@geo.uni-saarland.de)}

Saarland University - Campus Dudweiler: Universitat des Saarlandes - Campus Dudweiler https://orcid.org/00000001-9059-4938

Jochen Kubiniok

Saarland University: Universitat des Saarlandes

\section{Research}

Keywords: Nitrates, pesticides, watercourses, springs, non-point-source inputs, EC-WFD, intensive agriculture

Posted Date: December 20th, 2021

DOI: https://doi.org/10.21203/rs.3.rs-1133753/v1

License: (c) (i) This work is licensed under a Creative Commons Attribution 4.0 International License. Read Full License 


\section{Abstract}

\section{Background:}

Interflow-dominated spring waters provide a comprehensive picture of emissions with nitrate and other pollutants caused by the type and intensity of land use in the topographic catchment area. One aim of this study was to develop a model for predicting the share of nitrate pollution from non-point sources based on the type of agricultural use in the catchment areas of small and medium-sized watercourses.

\section{Methods:}

Fifty-five springs in Saarland and the adjacent Rhineland-Palatinate were monitored for pollutants during three monitoring periods of at least twelve months duration between 2000 and 2019. The catchment areas are representative of the natural regions in the study area and are outside the influence of settlements and other developments. In addition to nitrate and other physicochemical parameters, 25 agriculturally impacted springs were screened for pesticides and their metabolites.

\section{Results:}

Since the first measurements were taken in 2000, the vast majority of agriculturally impacted springs have consistently exhibited high nitrate concentrations of between 20 and $40 \mathrm{mg} / \mathrm{L} \mathrm{NO}_{3}{ }^{-}$. Springs not influenced by agriculture contain an average of $3.6 \mathrm{mg} / \mathrm{L}$ of nitrate. The extreme values observed in the early $2000 \mathrm{~s}$ decreased to the limit value of $50 \mathrm{mg} / \mathrm{L}$, but most of the springs with moderate levels exhibited an increase to approximately 30 $\mathrm{mg} / \mathrm{L}$. The number of pesticidal agents detected in the spring waters demonstrates a clear correlation with the intensity of agricultural usage and the nitrate content detected. A regression model derived from the highly significant correlation between nitrate content and the share of cropland in the catchment area can be used to quantify the share of nitrate pollution attributable to non-point-source inputs for larger catchments in the region under investigation.

\section{Conclusion:}

Nitrate discharged from farmland has not decreased since the EC WFD entered into force. At the extremely heavily polluted sites of the past, measures have been implemented in the meantime that have led to compliance with the limit value of the Nitrate Directive. As below this limit, nitrate levels are increasing significantly, we suggest to incorporate the marine ecology target as a binding mark for official water pollution control in the future.

\section{Introduction And Objectives}

Springs are natural conduits through which groundwater flows from aquifers into surface water bodies. They are considered the starting point for watercourses and, depending on their hydrological-morphological characteristics, provide diverse habitats for aquatic and amphibious plants and animals [1,2]. The chemical composition of spring water provides a picture of the pollutant load of the body of groundwater that feeds it. Indicators and trends in the pollution level of the groundwater can therefore be demonstrated by means of longer-term monitoring programs at springs [3]. Of particular importance are springs that are predominantly fed by interflow, which is the groundwater near the surface in the upper soil horizons. The degree of pollution in the water from these springs is largely determined by the emission of substances stemming from the respective forms of usage and management in the topographic catchment areas. Depending on the geological parent substrate and pedological conditions, residues of 
pesticides or fertilizers, for example, are retained to varying degrees or flushed out of the soil and discharged into surface waters via springs.

Nitrate is a significant pollutant in surface waters and groundwater; it leads to aquatic eutrophication and the associated consequences, when concentrations are excessive. It is discharged into bodies of water from both point sources and non-point sources [4-6]. Non-point-source inputs of fertilizers leached from farmland or atmospheric deposition dominate outside of settlements and commercial areas [6, 7]. The geological baseline situation, the resulting soil properties and groundwater dynamics as well as the variability of precipitation modify the transport of nitrate into surface waters [8]. Particularly in areas with large-scale, intensive agricultural use and soils with low water retention capacities, agricultural inputs constitute the most significant component of pollution. In addition to the geogenically or pedogenically related nitrate retention capacity, the type of agricultural use also plays an important role. For example, agricultural land that is managed according to the rules of organic farming exhibits significantly lower leaching rates across the entire crop rotation than conventionally cultivated areas [9].

In order to reduce nitrate pollution in surface waters, various limit values, environmental quality standards and target values have been set at the administrative level in the past. The European Water Framework Directive (WFD) provides for a limit value of $50 \mathrm{mg} / \mathrm{L}$ of annual average concentration for compliance in terms of the good chemical status of surface waters, as does the corresponding national implementation legislation [10, 11]. In addition, to protecting coastal waters and oceans, "maximum annual inland nitrogen concentrations" have been identified as target values for water resources management in Germany $[12,13]$. For the low mountain regions, this value is 3.2 $\mathrm{mg} / \mathrm{L} \mathrm{TN}$ (total nitrogen), which corresponds to a maximum value of $14.2 \mathrm{mg} / \mathrm{L}$ of nitrate. While the limit value of the WFD derives from a process of negotiation between the scientifically based minimization requirement and what is economically and politically feasible, the marine ecology target value is based on large-scale modeling calculations of the ecological carrying capacity of the seas.

Regular measurements of the pollutant load of watercourses within the context of official water resources management are generally taken at monitoring sites on the middle and lower reaches. This enables the summary recording of all pollution parameters for the sub-catchment concerned. However, the extent to which a differentiated analysis of individual sources of pollution can be conducted is limited. Substance input models, which provide results of varying accuracy depending on the degree to which the input parameters are aggregated, are often used to estimate the respective share of point and non-point-source inputs to the total load [14]. The pollutant emitters can be identified even more clearly by monitoring springs and headwaters with a detailed recording of the forms of use in their catchment areas $[15,16]$. In the absence of settlements, commercial areas and major transport routes, elevated nitrate levels are usually due to the type and intensity of agricultural use $[17,18]$.

Several studies have already been conducted in recent decades to determine the nitrate polltion and nitrate dynamics in spring waters [3,19-24]. These are primarily springs with consistently high discharge and are often located in karst areas. In the meantime, the influence of agricultural use on nitrate levels has also been demonstrated at smaller springs with low, often variable flow rates [8, 25-27]. Field studies also demonstrate the close relationship between dissolved nitrate in the soil moisture of agricultural fields and the concentration in the spring water of the corresponding catchment area [28]. Whereas soil moisture samples taken with the aid of lysimeters can only provide spatially limited data that are representative of the field from which they are collected, spring waters integrate the diverse uses throughout the catchment area. As forest and grassland areas discharge comparatively low levels of nitrate [29], we can assume that the share of cropland in the spring catchment area is decisive for the nitrate content of agriculturally impacted springs. This means that, for any given watercourse with 
various sources of pollution, the share of non-point-source nitrate inputs from agriculture can be estimated based on knowledge of the share of cropland in the catchment area. As a basis for such a forecast model, it is necessary to study a sufficient number of representative spring catchment areas which are similar to the catchment area of the watercourse for which the forecast is being made in terms of both agricultural use and geological and ecological baseline conditions. Point-source inputs of nitrate, e.g. from urban wastewater, are to be excluded in the spring catchment areas. If a significant relationship is demonstrated between the share of agricultural land and nitrate content in the spring waters, a regression model can be used to estimate the contribution of non-point-source inputs from agriculture to the nitrate content at the outlet of the catchment area of the forecast watercourse. One aim of this study was to develop approaches for such a forecast model on the basis of extensive monitoring of spring waters in an agriculturally-dominated low mountain landscape over almost two decades. The findings will be used to quantify the contribution of different emitters to the nitrate loads at the surface water monitoring sites and thus facilitate the derivation of targeted measures to reduce them.

Against this background, nitrate concentrations at 55 springs in Saarland and the adjacent Rhineland-Palatinate were monitored repeatedly between October 2017 and April 2019. In terms of area, the sampling sites are evenly distributed within the principal geological units dominating the study area. Sampling was conducted at monthly intervals, which provides a sufficiently accurate picture of the pollution profiles of the springs compared to timeconsuming continuous measurements [29]. The monitoring network had already been established and successively expanded between 2000 and 2001. Monitoring was conducted during an initial twelve-month period in 2002, and monthly sampling was resumed from July 2010 to July 2011. It was already possible to establish a close correlation between the degree of arable land use and the nitrate content of the spring water at that time [27, 28]. However, no clear trend in nitrate concentration ratios was identified from one monitoring period to another.

This study represents the second iteration of the monitoring series and aims to answer the following questions:

- What is the current nitrate pollution of springs with an agriculturally-dominated catchment area? How do the values compare with limit values and target values or with the pollution levels of largely unaffected forest springs?

- Can any differences or trends be identified with respect to pollution levels during 2002 or 2011-12 and, if so, to what can these be attributed?

- How clear is the relationship between nitrate pollution and the intensity of agricultural usage, and are there any differences between the three monitoring periods? Can this be used to develop a forecast model for estimating the contribution of non-point-source inputs to the nitrate load of a surface water body?

- Is there evidence of the role of interflow in nitrate inputs to surface waters?

- To what extent are the springs in the study also contaminated with plant protection products (PPPs)? Is the pattern of pollution with pesticidal agents similar to that of nitrate?

In order to answer these questions, in addition to the new monthly monitoring campaign spring water samples were also analyzed for pesticides and their transformation products. In addition, further measuring facilities were installed to sample the near-surface groundwater in the vicinity of selected springs.

\section{Methodology}


The study was conducted at 55 springs in Saarland and the adjacent Rhineland-Palatinate (southwest Germany). All surface waters drain to the Rhine via the rivers Saar, Moselle and Nahe.

The low mountain landscape of the study area is characterized by a varied relief which is dominated by the prominent scarps of the Upper Muschelkalk (Middle Triassic) and the Upper Bunter sandstone (Lower Triassic) [30], particularly in the southeast and west. Between these, the zones of the Middle Bunter sandstone and the Middle and Lower Muschelkalk form more or less extensive plains and gentle slopes. The central part is dominated by Carboniferous and Permian (Rotliegend) sediments and individual Permian volcanic rocks, which form an irregular hilly relief. In the north, the Devonian metamorphic rocks of the Hunsrück mountain range, an offshoot of the Rhenish Slate Mountains, form the highest elevations and steep ridges with elevations ranging from $160 \mathrm{~m}$ above sea level in the lower Saar valley to over $650 \mathrm{~m}$ above sea level in the Hunsrück range.

The sampling sites in the Muschelkalk are located in the Bliesgau region in the southeast of Saarland and in the northwest in the Saar-Mosel-Gau. On gentle slopes and in smaller valleys of the Gau landscapes, Eutric Cambisols and Luvisols create relatively favorable conditions for agricultural use, while soils on the steep slopes of the stratified levels are less fertile. Four of the ten springs studied in the Muschelkalk are slightly influenced by agriculture, with an agricultural area $<25 \%$ of the catchment area.

Most of the springs that were sampled in the Bunter sandstone (Lower Triassic) are located in the southeastern part of Saarland and belong to the "Saarbrücken-Kirkeler Wald" region, while three of them are located in the northwest, in the foothills of the Hunsrück range. The predominant soils in the catchment areas are Eutric and Dystric Cambisols with low cation exchange capacities (CEC), low water retention capacities and low buffering capacities. Because the Bunter sandstone areas are typically used for forestry and woodland, only three of the sites are classified as open land springs (agricultural area $>25 \%$ ).

The springs in the central and eastern part in the Rotliegend (Lower Permian) stratigraphic unit are primarily characterized by Cambisols and Luvisols on more or less sandy to clayey substrata. Three of the Rotliegend springs are located in zones of clay-rich, acidic cambisols derived from Permian volcanics. The fertility of the soils is very heterogeneous and depends on the relief and the geochemical baseline condition of the respective petrographic subzone. Four of the 14 springs in the Rotliegend are considered to be largely unaffected by agriculture, with agricultural land use at $<1 \%$ and forest cover being $>95 \%$. In eight springs, this share is well above $25 \%$, although only three catchment areas with an agricultural predominance of $>80 \%$ can be characterized as genuine agricultural springs.

The Carboniferous zone in Saarland is predominantly characterized by forest and settlement areas ("Saarkohlenwald"). The parent rock consists of siltstones, argillites, sandstones, quartzitic shales and outcropping coal seams, which primarily generate Dystric Cambisols, Stagnic/Gleyic Luvisols and Dystric Gleysols. The five Carboniferous springs with catchment areas in which agriculture accounts for more than $50 \%$ of land use are located in zones with loamier soils on the northern edge of the Saarkohlenwald region.

The parent rock of the northern catchment areas in the Hunsrück foothills is dominated by Devonian acidic quartzites (Taunus quartzite) and slates. The waters of the southernmost locations are also influenced by the rocks of the Bunter sandstone. The predominant soils, Dystric Cambisols, Dystric and Lithic Leptosols, have low water retention capacities, low CECs and low buffering capacities. All catchment areas in the Devonian zone are more than $95 \%$ forested. 
The climate in the study area is temperate oceanic and characterized by mild temperatures and a balanced annual cycle of precipitation with a slight maximum during the winter period. An annual mean temperature of $9.0^{\circ} \mathrm{C}$ and an annual total precipitation of $1031 \mathrm{~mm}$ are given as multi-year averages for the normal period from 1981 to 2010 at the Tholey station in the central area of Saarland [31].

Table 1

Annual total precipitation $(p)$ and mean temperature $(T)$ of three monitoring periods in comparison with the long-term average (Tholey weather station, German Weather Service)

\begin{tabular}{|lllll|}
\hline & Long-term Average & \multicolumn{3}{l|}{ Monitoring Periods } \\
\hline & $1981-2010$ & 2002 & $2011-12$ & 2018 \\
\hline $\mathrm{p}$ total $[\mathrm{mm}]$ & 1031 & 1281 & 958 & 966 \\
\hline $\mathrm{T}$ mean $\left[{ }^{\circ} \mathrm{C}\right]$ & 9.0 & 9.8 & 9.4 & 11.0 \\
\hline
\end{tabular}

The weather pattern during the three monitoring periods deviates, more or less, from the multi-year average. While the first year of the study (2002), with a total precipitation of $1281 \mathrm{~mm}$, was clearly wetter than the multi-year mean (24\% higher), the other two monitoring periods were slightly drier (see Table 1 ). In terms of average annual temperatures, 2018 was $11^{\circ} \mathrm{C}$, or $2^{\circ}$ above the multi-year average. Across Germany, it is considered the warmest year since weather records began. The other two monitoring periods, on the other hand, were only slightly warmer than the average in the study area, $+0.8^{\circ}(2002)$ and $+0.4^{\circ}(2011-12)$. Prolonged periods of low precipitation combined with prolonged high temperatures led to extreme dry spells in the summer and autumn of 2018.

The 55 springs included in the study are, for the most part, evenly distributed over the most important geological units in Saarland (see Fig. 1). In terms of topography, geology and land use structure, they can be considered representative of the rural parts of the study area. The designation of the sampling sites was based on the initial letter of name of the respective main lithological/geological unit (German).

All springs are located outside the influence of settlements, commercial areas and wastewater discharges. The sampling sites exhibit very different degrees of development, ranging from near-natural seepage springs to spring outcrops restructured as wells. Some springs in agricultural lands also partially tap into cropland drainages. The morphological structure, naturalness, and bulk flow characteristics were documented for each sampling site in order to identify potential effects on the chemical composition of the spring waters. It has been shown that the nitrate content is largely unaffected by the structural characteristics of the spring; therefore, no further consideration of this parameter is presented below.

\section{Land use in the spring catchment areas}

The catchment areas of the sampling sites were delineated using a geoinformation system based on a digital terrain model (DGM5) of the State Office for Geoinformation and Land Development (LVGL, grid spacing $12.5 \mathrm{~m}$, dated 2010). The results were validated and corrected using topographic data and field observations. Initially, aggregated usage based object classes from the ATKIS (Authoritative Topographic-Cartographic Information System - dated 2010) data of the LVGL served as the basis for mapping land use within the catchment areas delineated in this way [32]. The delineation of each type of land use was verified using digital infrared orthophotos (dated 2012) and then remapped in the field. A comparison of the mapping from the three monitoring periods did 
not reveal any significant changes in the proportions of land use types in the spring catchment areas over the past two decades.

Farmland accounts for more than 25\% of the topographic catchment areas for 22 of the 55 springs studied. The shares of grasslands, croplands and total agricultural area for these springs are shown in Table 2. Four other springs are only slightly influenced by agriculture, which accounts for between $10 \%$ and $15 \%$ of the land use. All other sites can be considered as largely unaffected by agriculture, with agricultural land use at $<5 \%$. The areas of the 55 topographic spring catchments range from 1.3 ha to 92 ha. About half of the catchment areas are smaller than 10 ha. These smaller catchment areas occur primarily in the Bunter sandstone (Lower Triassic), Rotliegend (Lower Permian) and Carboniferous.

The croplands in the catchment areas studied are predominantly used for the cultivation of cereals, maize and rape. Root crops or specialty crops are not represented. The croplands and grasslands are regularly treated with organic and mineral fertilizers at varying intensities according to the fertilizer regulations in force in Germany.

\section{Sampling and analysis Monitoring of spring waters}

The first spring monitoring phase began in 2000 with monthly sampling that focused on forest springs. As the program progressed, the monitoring network was modified and steadily expanded to the main geological units in Saarland. The resulting monitoring network of 55 springs was first studied in 2002 with monthly sampling over the course of an entire year. An initial follow-up investigation was conducted between July 2010 and June 2011 . The third and final monitoring period began in October 2017 (until April 2019). The twelve-month comparator period for the other two monitoring periods was from the beginning until the end of 2018.

Although some springs had been deformed during the course of nearly two decades since the beginning of the first sampling program and therefore had to be replaced by other monitoring sites, 50 of the original 55 sites are still available for a multi-year comparison.

Monthly sampling involved collecting a grab sample from the open channel bed immediately downstream from the spring's outcrop. The $\mathrm{pH}$, electrical conductivity, dissolved oxygen, and temperature were measured using a handheld meter (WTW MultiLine Multi 3430) immediately after sampling in the field. The samples were filled into PE bottles and kept refrigerated at $4^{\circ} \mathrm{C}$ for further analysis in the laboratory. Ammonium and nitrate ions were analyzed within 24 hours after sampling in accordance with DIN 38405 [33]. Reserve samples were deep-frozen at $-20^{\circ} \mathrm{C}$ for any subsequent measurements. A check was carried out for internal quality control by adding a standard to each series of measurements for selected samples.

DIN 38405-29 [34] served as the basis for the nitrate measurement. Samples were mixed with Merck "Spectroquant ${ }^{\circledR}$ " nitrate test and measured by UV/VIS spectrophotometer at $340 \mathrm{~nm}$. The limit of determination specified by the manufacturer is $4.4 \mathrm{mg} / \mathrm{L}$ of nitrate. Ammonium was measured photometrically according to DIN 38406 [35] using a spectrophotometer at $690 \mathrm{~nm}$. The Merck ammonium test from the "Spectroquant@" product range was used. The limit of determination specified by the manufacturer is $0.06 \mathrm{mg} / \mathrm{L}$ of ammonium.

For averaging and further evaluation, all values below the limit of determination were set to half the limit of determination according to the recommended procedures for water monitoring in Germany [11].

\section{Near-surface groundwater - Piezometers}


In addition to the monitoring sites at the springs, piezometers were installed at selected sites for sampling the nearsurface groundwater in order to differentiate the lateral and vertical transport paths of the discharged nitrate. The piezometers are stainless steel tubes (diameter approx. $30 \mathrm{~mm}$ ) with a closed tip at the lower ends which allows them to be driven into the ground. A filter section with longitudinal slots (length $78 \mathrm{~mm}$, slot width $0.35 \mathrm{~mm}$ ) above the tip allows the infiltration of soil moisture or groundwater. The piezometers were installed at different depths in the colluvial area of the depth contour below the selected springs. Samples were collected by pumping out the infiltrated water at monthly intervals.

The aim of the study was to randomly determine possible differences in infiltration behavior as a function of the geogenic substrate. Sampling sites for this purpose were initially selected in the Rotliegend (Lower Permian), which plays an important role in terms of area in central Saarland. The soils in this zone are mostly sandy-loam, with some silty-clays, and have medium water retention capacities. As a contrast, two additional sites were identified in the area of sandy, permeable soils in the Bunter Sandstone (Lower Triassic). The locations of the piezometers are shown in Fig. 1.

A total of eleven sampling events were conducted at the Rotliegend sites from February to December 2020. As it has been demonstrated that the nitrate contents of the groundwater samples fluctuate very little over the course of the year, the monitoring sites in the Bunter sandstone, which were not installed until December 2020, were only sampled three times up to and including April 2021. Grab samples were collected from the springs upgradient of the piezometers at the same time that the piezometers were sampled.

The water samples were poured into PE bottles, using a procedure similar to that for sampling at the springs, and kept chilled at $4^{\circ} \mathrm{C}$. They were then filtered and analyzed for nitrate content according to the procedure described above.

\section{Plant protection products}

In 2019 , water samples from 25 spring sites in the monitoring program that were heavily impacted by agriculture were analyzed for their levels of pesticides and the associated degradation products. The samples were collected in April, June and October. Among the sampled springs were three forest springs (percentage of agricultural land $<5 \%$ ), which served as potentially uncontaminated reference sites.

The grab samples were collected manually on each occasion. The unfiltered water was bottled in brown glass bottles, and then stored in a cooler. The samples were subjected to an unbroken cold chain at $4^{\circ} \mathrm{C}$ from the time of collection until analysis. The Speyer Agricultural Investigation and Research Institute (LUFA) analyzed the water samples for a total of 251 organic substances using a procedure analogous to that used in an earlier study on pesticides in headwaters [36]. This included not only pesticides and their metabolites but other organic micropollutants such as drug residues and biocides as well. The analysis was performed by LC-MS/MS (liquid chromatography with tandem mass spectrometry coupling) in accordance with DIN 38407-36 [37].

\section{Results}

\section{Physicochemical characterization of the agriculturally impacted springs}


In addition to potential contaminations, the $\mathrm{pH}$, oxygen content, water temperature $(\mathrm{T})$ and temperature amplitude over the course of the year $(\Delta T)$ as well as the electrical conductivity (EC) are essential for the geoecological characterization of the spring waters. A total of 55 springs were studied between 2002 and 2018 . Twenty-two springs with farmland accounting for more than $25 \%$ of land use are considered potentially influenced by agriculture. Table 2 lists selected physicochemical parameters from the 2018 monitoring period.

The $\mathrm{pH}$ of the spring waters influenced by agriculture are in the neutral range, between 6 and 8 , and therefore do not exhibit any extreme values. In consonance with the lithology of the catchment areas, all the sites in the Muschelkalk and two springs each in the Rotliegend and the Bunter sandstone exhibit rather basic conditions, while all other spring waters are slightly acidic on average. The springs in the Muschelkalk exhibit significantly higher conductivity values than almost all the other sites; this is due to the high solubility of the minerals of the carbonate parent rock.

With the exception of a single heavily modified site (b06) the mean oxygen contents are well above the critical range of $3 \mathrm{mg} / \mathrm{L}$ for fish and many other aquatic organisms. However, the orientation value for good ecological status according to the German Surface Water Ordinance [11] of $8 \mathrm{mg} / \mathrm{L}$ is undercut by the annual average at seven locations and at least once over the course of the year at 13 locations. 
Table 2

Median values of selected physicochemical parameters and land use of 22 springs influenced by agriculture

\begin{tabular}{|c|c|c|c|c|c|c|c|c|c|c|c|c|}
\hline $\begin{array}{l}\text { Spring } \\
\text { ID }\end{array}$ & $\mathrm{NO}_{3}{ }^{-}$ & $\mathrm{NH}_{4}^{+}$ & EC & $\mathrm{T}$ & $\Delta \mathrm{T}$ & $\mathrm{pH}$ & $\mathrm{O}_{2}$ & $\begin{array}{l}\mathrm{O}_{2} \\
\mathrm{~min}\end{array}$ & Farmland & Cropland & Forest & Area \\
\hline b06 & 2.20 & 0.09 & 892 & 8.7 & 15.8 & 7.3 & 1.8 & 0.0 & $25.5 \%$ & $0.0 \%$ & $73.2 \%$ & 14.0 \\
\hline b07 & 13.45 & 0.12 & 330 & 11.0 & 11.9 & 6.7 & 7.4 & 1.4 & $79.2 \%$ & $1.9 \%$ & $19.7 \%$ & 14.8 \\
\hline b08 & 29.55 & 0.08 & 353 & 11.4 & 12.1 & 7.1 & 9.2 & 8.3 & $81.9 \%$ & $25.5 \%$ & $6.9 \%$ & 9.9 \\
\hline k05 & 32.10 & 0.08 & 360 & 11.3 & 7.6 & 6.6 & 9.5 & 8.4 & $91.1 \%$ & $59.5 \%$ & $2.9 \%$ & 1.5 \\
\hline k06 & 18.00 & 0.10 & 287 & 9.0 & 8.9 & 6.1 & 8.5 & 5.9 & $57.8 \%$ & $11.9 \%$ & $32.1 \%$ & 7.3 \\
\hline k08 & 38.05 & 0.03 & 182 & 11.2 & 7.2 & 6.3 & 9.2 & 7.8 & $76.3 \%$ & $54.1 \%$ & $22.1 \%$ & 58.0 \\
\hline k09 & 13.80 & 0.03 & 237 & 8.7 & 13.1 & 6.7 & 10.7 & 8.0 & $85.6 \%$ & $15.4 \%$ & $14.4 \%$ & 3.8 \\
\hline k10 & 52.60 & 0.03 & 342 & 11.1 & 5.1 & 6.7 & 7.5 & 6.4 & $82.9 \%$ & $73.0 \%$ & $17.1 \%$ & 16.8 \\
\hline $\mathrm{m} 02$ & 12.95 & 0.15 & 595 & 7.7 & 11.8 & 7.3 & 8.5 & 2.3 & $89.3 \%$ & $38.6 \%$ & $3.8 \%$ & 17.4 \\
\hline $\mathrm{m} 03$ & 21.30 & 0.05 & 722 & 12.0 & 5.5 & 7.4 & 8.4 & 7.8 & $93.0 \%$ & $79.4 \%$ & $2.0 \%$ & 32.9 \\
\hline $\mathrm{m} 07$ & 12.30 & 0.13 & 705 & 11.9 & 7.3 & 7.3 & 8.6 & 5.4 & $26.9 \%$ & $6.7 \%$ & $73.1 \%$ & 62.2 \\
\hline $\mathrm{m} 08$ & 52.40 & 0.11 & 692 & 11.2 & 6.2 & 7.4 & 9.8 & 8.0 & $82.5 \%$ & $72.3 \%$ & $15.7 \%$ & 53.9 \\
\hline m09 & 13.95 & 0.14 & 630 & 11.5 & 12 & 7.9 & 10.5 & 8.0 & $93.6 \%$ & $51.2 \%$ & $6.4 \%$ & 39.1 \\
\hline m10 & 49.45 & 0.05 & 698 & 10.6 & 2.1 & 7.3 & 10.4 & 10.1 & $93.1 \%$ & $76.3 \%$ & $0.7 \%$ & 92.4 \\
\hline r01 & 39.15 & 0.03 & 283 & 10.6 & 3.2 & 6.7 & 9.6 & 9.4 & $72.1 \%$ & $72.1 \%$ & $27.9 \%$ & 3.8 \\
\hline r02 & 21.50 & 0.11 & 225 & 11.2 & 4.9 & 6.3 & 7.5 & 6.5 & $46.4 \%$ & $38.4 \%$ & $53.6 \%$ & 7.9 \\
\hline r03 & 24.90 & 0.03 & 447 & 10.4 & 2.8 & 7.7 & 7.9 & 6.5 & $64.0 \%$ & $45.6 \%$ & $34.7 \%$ & 55.3 \\
\hline r09 & 34.15 & 0.11 & 244 & 11.3 & 11.3 & 7.2 & 9.7 & 8.3 & $89.7 \%$ & $89.7 \%$ & $3.6 \%$ & 2.5 \\
\hline r12 & 30.80 & 0.06 & 417 & 11.7 & 3.3 & 6.6 & 9.7 & 9.0 & $82.9 \%$ & $32.6 \%$ & $5.3 \%$ & 10.7 \\
\hline r13 & 32.80 & 0.09 & 223 & 10.7 & 6 & 6.3 & 9.7 & 9.3 & $51.6 \%$ & $51.6 \%$ & $48.4 \%$ & 5.1 \\
\hline $\mathrm{r} 14 \mathrm{a}$ & 27.40 & 0.26 & 202 & 8.3 & 19.3 & 6.0 & 6.9 & 3.8 & $56.6 \%$ & $56.6 \%$ & $43.4 \%$ & 1.5 \\
\hline $\mathrm{r} 14 \mathrm{~b}$ & 41.05 & 0.20 & 248 & 10.6 & 14.2 & 6.6 & 6.7 & 3.0 & $90.5 \%$ & $90.5 \%$ & $9.5 \%$ & 3.7 \\
\hline
\end{tabular}

$\mathrm{NO}_{3}{ }^{-}, \mathrm{NH}_{4}{ }^{+}$and $\mathrm{O}_{2}$ in $\mathrm{mg} / \mathrm{L}, \mathrm{EC}$ in $\mu \mathrm{S} / \mathrm{cm}, \mathrm{T}$ and $\Delta \mathrm{T}$ in ${ }^{\circ} \mathrm{C}$, area in ha

The correlations of selected physicochemical parameters using the correlation matrix in Table 3 demonstrate a clear correlation of nitrate concentrations with the shares of farmland and cropland. In contrast, electrical conductivity (EC) exhibits a much weaker correlation with farmlands and croplands $(r<0.5)$. The low correlation coefficient of $r=$ 0.29 between $\mathrm{NO}_{3}{ }^{-}$and $\mathrm{EC}$ indicates that $\mathrm{EC}$ is likely dominated more by the solubility of the components of the geogenic parent substrate and other material inputs than by nitrate. The weak positive correlation of ammonium 
values with temperature amplitude $\Delta T$ and the weak negative correlation with oxygen content $\left(\mathrm{O}_{2}\right.$ median and $\mathrm{O}_{2}$ $\mathrm{min}$ ) indicate the influence of surface runoff at some springs. Springs with elevated amounts of surface runoff, relative to groundwater and interflow, exhibit greater temperature amplitudes over the course of the year. Increased temperatures lead to lower oxygen levels during the summer months. This is indicated by the negative correlation of $\Delta \mathrm{T}$ and $\mathrm{O}_{2}$ min. The relationship to $\mathrm{NH}_{4}+$ suggests that ammonium enters predominantly via surface runoff, for example at livestock watering sites or from freshly fertilized land. Such relationships are found at springs $r 14 a, r 14 b$, and $\mathrm{m} 02$ (see Table 2). However, more than half of the agriculturally impacted springs exhibit very low ammonium levels $(<0.1 \mathrm{mg} / \mathrm{L})$ at significantly elevated $\mathrm{NO}_{3}$ - concentrations. As expected, the principal component of nitrogen inputs is nitrate, which enters surface waters primarily via interflow.

Table 3

Correlation matrix between selected parameters based on Pearson's correlation coefficient $r$

\begin{tabular}{|c|c|c|c|c|c|c|c|c|}
\hline $\mathbf{R}$ & $\mathrm{NO}_{3}^{-}$ & $\mathrm{NH}_{4}+$ & EC & $\Delta \mathrm{T}$ & $\mathrm{O}_{2}$ median & $\mathrm{O}_{2} \min$ & Farmland [\%] & Cropland [\%] \\
\hline $\mathrm{NO}_{3}^{-}$ & 1.00 & & & & & & & \\
\hline $\mathrm{NH}_{4}+$ & 0.00 & 1.00 & & & & & & \\
\hline EC & 0.29 & 0.14 & 1.00 & & & & & \\
\hline$\Delta \mathrm{T}$ & -0.18 & 0.49 & -0.11 & 1.00 & & & & \\
\hline $\mathrm{O}_{2}$ median & -0.03 & -0.44 & -0.27 & -0.27 & 1.00 & & & \\
\hline $\mathrm{O}_{2} \min$ & 0.07 & -0.49 & -0.20 & -0.51 & 0.82 & 1.00 & & \\
\hline Farmland & 0.80 & 0.09 & 0.47 & 0.00 & -0.07 & -0.09 & 1.00 & \\
\hline Cropland & 0.88 & 0.10 & 0.36 & -0.07 & -0.04 & 0.03 & 0.86 & 1.00 \\
\hline
\end{tabular}

\section{Interflow and groundwater}

In order to determine the seepage and transport behavior of the near-surface groundwater, piezometers were installed at seven springs in the Rotliegend and in the Bunter sandstone and added to the monitoring sites in the program. In several random samples, the nitrate content of the springs and groundwater were measured at depths of approximately $1 \mathrm{~m}$ and $2 \mathrm{~m}$. While the springs in areas where the predominant use is cropland exhibit elevated nitrate concentrations, as expected $(11-33 \mathrm{mg} / \mathrm{L}$ in the Rotliegend and $47.5 \mathrm{mg} / \mathrm{L}$ and $59.8 \mathrm{mg} / \mathrm{L}$ in the Bunter sandstone), these concentrations are significantly reduced in the near-surface groundwater samples (see Table 4). At a depth of approximately $2 \mathrm{~m}$, roughly $20 \%$ of the concentrations of the spring samples are still detected at the Bunter sandstone locations, while significantly lower values are detected in the upper horizons at depths of $1.2-1.4$ (see Table 5). 
Table 4

Nitrate concentration (mean) in piezometers and springs in Rotliegend / Lower Permian (numbers in sample ID indicate the sampling depth in $\mathrm{m} ; 0=$ spring)

\begin{tabular}{|llll|}
\hline Sample ID & Below ground $[\mathrm{m}]$ & Nitrate $[\mathrm{mg} / \mathrm{L})$ & $\%$ of spring concentration \\
\hline ra_0 & 0 & 24.2 & \\
\hline ra_2 & 2 & 0.3 & $1 \%$ \\
\hline rb_0 & 0 & 29.4 & $4 \%$ \\
\hline rb_1 & 1 & 1.1 & $2 \%$ \\
\hline rb_2 & 2 & 0.6 & $1 \%$ \\
\hline rc_0 & 0 & 48.8 & $1 \%$ \\
\hline rc_1 & 1 & 0.6 & 0.3 \\
\hline rc_2 & 2 & Numbers in sample-ID indicate the sampling depth in $\mathrm{m} ; 0=$ spring \\
\hline
\end{tabular}

Table 5

Nitrate concentration (mean) in piezometers and springs in Bunter sandstone / Lower Triassic (numbers in sample-ID indicate the sampling depth in m; $0=$ spring)

\begin{tabular}{|llll|}
\hline Sample ID & Below ground [m] & Nitrate [mg/L) & \% of spring concentration \\
\hline ba_0 & 0 & 59.8 & \\
\hline ba_1.4 & 1.4 & 1.7 & $3 \%$ \\
\hline ba_2 & 2 & 12.9 & $22 \%$ \\
\hline bb_0 & 0 & 47.5 & $4 \%$ \\
\hline bb_1.2 & 1.2 & 2.0 & $20 \%$ \\
\hline bb_1.9 & 1.9 & 9.8 & \\
\hline Numbers in sample-ID indicate the sampling depth in $\mathrm{m} ; 0=$ spring
\end{tabular}

The piezometer samples from the Rotliegend consistently exhibit nitrate concentrations of $<2 \mathrm{mg} / \mathrm{L}$, whereby the values at a depth of $1 \mathrm{~m}$ are regularly somewhat higher than at $2 \mathrm{~m}$. This demonstrates that in both the clayeyloamy soils of the Rotliegend and the sandy sites, the vertical transport of nitrate via infiltration is negligible in terms of quantity. The elevated nitrate concentrations of the piezometer samples from sites ba and bb at a depth of $2 \mathrm{~m}$ indicate that there is a connection to the respective groundwater body in both areas. The pollutions levels in both areas are clearly evident at approximately $10 \mathrm{mg} / \mathrm{L}$. There is no such groundwater body in the Rotliegend, which means that elevated nitrate levels cannot be detected even at greater depths.

\section{Nitrate levels in spring waters from 2002 to 2018}

The focal point of this study was nitrate pollution in springs with an agricultural catchment area (agricultural area $\geq 25 \%$ ). The measured nitrate concentrations at these 22 springs are, for the most part, clearly above $10 \mathrm{mg} / \mathrm{L}$ for all 
three measuring periods (see Fig. 2). An exception is site b06, which can be considered largely uncontaminated with nitrate levels of below $5 \mathrm{mg} / \mathrm{L}$. The share of agricultural usage in the catchment area here is only $25 \%$ and consists exclusively of permanent grassland. In addition, there is a $100 \mathrm{~m}$ wide area of forest and field copses between the grassland area and the spring outcrop; this can further reduce the relatively low discharge of nitrates expected from the grassland area.

All other springs under agricultural influence exhibit mean nitrate concentrations that are, at times, significantly above $10 \mathrm{mg} / \mathrm{L}$ (median from 12 monthly measurements). The marine ecology target value of $14.2 \mathrm{mg} / \mathrm{L}$ is exceeded at all springs during at least one of the three monitoring periods. Nitrate levels above $30 \mathrm{mg} / \mathrm{L}$ were detected at ten springs during at least one monitoring period. The annual average exceeded the 50-mg/L limit value from the Nitrate Directive at three springs.

A comparison of the mean nitrate levels (medians) for the three monitoring periods reveals no clear trend for 2002, 2011-12 and 2018. On the one hand, nitrate levels from the three springs, m08, $m 10$, and $k 10$, which had peak nitrate levels above $70 \mathrm{mg} / \mathrm{L}$ in 2002, leveled off relatively consistently to approximately $50 \mathrm{mg} / \mathrm{L}$ in 2011-12 and 2018. On the other hand, a trend towards increasing nitrate levels can be observed in numerous springs with moderate pollution levels. The limit values from the Nitrate Directive are exceeded in individual measurements at these springs; however, the mean and median values over twelve months are significantly lower.

In particular, the springs in the Rotliegend (r01 to r14), with mean nitrate concentrations of between 25 and $40 \mathrm{mg} / \mathrm{L}$ over the two decades considered, exhibit no improvement. In some cases, a significant increase in nitrate pollution was observed between 2002 and 2018. The reason for this is likely the intensification of agricultural use and the lack of regulatory requirements for nitrate emissions below the legal limit. At the three springs with peak values that had exceeded the limit value of $50 \mathrm{mg} / \mathrm{L}$ in the past, appropriate measures had apparently been implemented to reduce emissions to the level just permissible.

\section{Nitrate in springs without agricultural influence}

In order to determine the background pollution that cannot be attributed to the influence of agriculture, the monitoring program also included springs with predominantly forested catchment areas (forest share $>95 \%$ ). Agricultural land use accounts for $<1 \%$ of usage in the catchment areas of 24 springs; these springs can therefore be classified as largely unaffected by agriculture.

Fig. 3 shows the mean nitrate concentrations for the three monitoring periods and the medians of all measurements at the individual sites. The vast majority of these springs have consistently low nitrate levels of well below $10 \mathrm{mg} / \mathrm{L}$. The determination limit for the analytical method was consistently undershot in 13 springs during 2018. Individual outliers, such as t04, t05, b12 and k12 were due to silvicultural activities such as clearing and/or the deposition of cuttings. The area around k01 is also strongly influenced by the activities of the former coal mining industry. In addition to local fills and excavations, there are also large-scale clearings and accumulations of residual wood.

The median of all measured values from the three periods is $3.26 \mathrm{mg} / \mathrm{L}(\mathrm{N}=769$; see gray line in Fig. 3). The mean nitrate values from the three monitoring periods for the 24 forest springs (2002: $3.45 \mathrm{mg} / \mathrm{L} ; 2011-12: 2.2 \mathrm{mg} / \mathrm{L}$; 2018: $2.75 \mathrm{mg} / \mathrm{L}$ ) are shown as comparison values in Fig. 2. Taking into account the $\pm 2.3 \mathrm{mg} / \mathrm{L}$ measurement inaccuracy of the analytical method specified by the manufacturer, this results in a mean concentration of $5.6 \mathrm{mg} / \mathrm{L}$ nitrate as the threshold value for anthropogenic pollution in the study area. Nitrate levels that are clearly above this level therefore indicate increased anthropogenic inputs. 


\section{Seasonality of the nitrate content in comparison of the three monitoring periods}

Due to its high degree of solubility, the release of nitrate from the soils of the agricultural areas into the spring waters depends, to a large extent, on the hydroclimatic conditions during the periods under consideration. During the growth phase, vegetation can absorb and thus retain a major part of the nitrate, even during heavier precipitation. Retention decreases sharply after the harvest and toward the end of the growing season in autumn, and the nitrate in the soil, which is released from fertilizer residues and now increasingly from decomposed, dead plant parts, can be freely washed out with the seepage. Considerable pollution peaks can particularly be expected after longer dry phases during late summer and autumn.

The three monitoring periods exhibit clear differences with regard to precipitation and temperature conditions. While annual precipitation for the 2011-12 and 2018 periods is slightly below the multi-year average for the 1981-2010 normal period, it exceeds the average by more than one-fifth in 2002 (see Table 1). The annual average temperatures for the first two periods are only slightly above the multi-year average. However, at almost $2^{\circ} \mathrm{C}$ above the multi-year mean, 2018 was significantly warmer than the other monitoring periods.

Differences in the monthly precipitation conditions over the course of the year can also be observed (see bars in Fig. 4). The highest amounts of precipitation generally occurred during the winter months for all three periods. However, the maximum for 2002 was in February, and the values for October and November clearly exceed those of December and January. During 2011-12 and 2018, on the other hand, a much drier autumn was followed by maximums in December and January. The 2011-12 phase is also characterized by a summer with relatively high precipitation.

To compare the trend of nitrate contents for the three monitoring periods during the course of the year, the monthly measured values are presented along with the monthly precipitation totals. Fig. 4 shows the annual trends of nitrate concentrations for two representative springs along with the monthly precipitation totals. As the measurements for the 2011-12 period were taken between July 2011 and June 2012, the monthly data for the two six-month periods, $2 / 2011$ and $1 / 2012$, are presented in reverse order for better comparability with the other monitoring periods. Thus, the period begins with January 2012 and ends with December 2011 and is referred to as the 2012-11 period for this review.

Nitrate pollution is relatively uniform without major peaks over the course of the year for the 2002 and 2018 monitoring periods at both sites, with the minimum in spring (March-April) and a continuous increase from MayAugust to the maximum in autumn/winter (beginning in October). This occurs largely in parallel with the monthly precipitation levels. At Bunter sandstone site b08, this was much more pronounced during 2018, which was a very warm, dry year, than in 2002, which was wet. At this site, the temporary maximums and minimums follow the precipitation curve somewhat, but there is some interference due to retention by vegetation during the growth phase (March-April), fertilization (increase May-June) and leaching after harvest (beginning in August). Heavy precipitation is less noticeable during the growing season (June) than in autumn/winter. At site m08, on the other hand, with the exception of the period from 2012-11, a very uniform course of nitrate pollution can be observed. This can be interpreted as a consequence of the different nitrate retention capacities of the two catchment areas. The predominantly sandy substrate in the Bunter sandstone at b08 has a good percolation capacity and a low retention capacity, whereby free nitrate in the soil solution, which comes from fertilizer applications or the decomposition of biomass, is discharged without delay to the spring via interflow during precipitation events. The clayey soils with

Page $14 / 25$ 
shell limestone have greater water retention capacities and can retain significantly larger amounts of nitrate. With a well-equilibrated water balance and an existing nitrate surplus, leaching here is relatively continuous. The strong fluctuations at site b08 during the 2012-11 monitoring period can be explained by the intermittent drying up of the spring during the summer months.

\section{Dependence of nitrate content on land use}

The relationships between nitrate levels and some selected metrics have already been discussed above for the 2018 monitoring period. The strongest dependence is on the type of agricultural land use. There is a highly significant positive correlation with the share of cropland in the catchment area of the spring $(r=0.88 ; p<0.01)$. Grassland usage, on the other hand, has a much lesser impact on nitrate emissions in the catchment area. The correlation between the share of grassland and the mean nitrate concentration in the spring water is only slightly positive with $r$ $=0.24$ and not significant $(p=0.07)$ (see Fig. 5). This demonstrates that the highest nitrate emissions come from croplands, whereas grassland usage tends to have a neutral or even reducing effect on water pollution through dilution.

A comparison of the 50 springs for which measured values are available from all three monitoring periods reveals a highly significant correlation between the nitrate content and the share of cropland $(p<0.01)$. Fig. 6 shows the regression lines for the three monitoring periods. The correlation coefficient increased slightly from $2002(r=0.82)$ to 2011-12 and $2018(r=0.87)$. When considering only those springs with a significant agricultural influence in terms of area (agricultural area >25\%), the 2002 and 2018 correlation is highly significant, and 2011-12 is significant $(p<0.05)$. Again, the significance of the correlation increased from 2002 to 2018.

A comparison of the regression lines for the three monitoring periods in Fig. 6 shows a very similar trend with almost the same slope. This correlation can be used to develop a regression model that estimates the mean nitrate concentrations attributable to non-point-source inputs, particularly from agriculture, based on the share of cropland in the catchment area.

Using the 150 median values of the twelve monthly measurements from the three periods, a coefficient of determination of $\mathrm{R}^{2}=0.72$ yields a regression coefficient of $\mathrm{m}=43.7$ and a y-intercept $\mathrm{b}$ of 5.7 .

The corresponding regression equation for predicting the potential nitrate content as a function of the share of cropland is:

\section{$C_{\text {nps }} \mathrm{NO}_{3}^{-}$in catchment $i=5.7+43.7 * P_{C L}$ in catchment $i$}

where, $C_{n p s}$ stands for the predicted nitrate content in the watercourse caused by non-point sources in the selected catchment area $i$, and $P_{C L}$ represents the share of cropland in the selected catchment area $i$ in terms of area.

As already shown above, the investigated spring catchment areas are to be regarded as representative in terms of topography, geology and land use structure for the rural regions of Saarland. Springs dominated by forest or grassland as well as sites with predominantly cropland areas were included. The relatively low nitrate emissions from the forest and grassland areas are included as a constant in the regression model via the $y$-axis intercept. Thus, the determined concentration $C_{n p s}$ at the monitoring site i of any watercourse in the study area represents the amount that is not caused by settlements or other point sources. Consequently, the share of point-source inputs can 
be estimated by taking the difference between the measured nitrate concentration at monitoring site $i$ and the predicted value $C_{n p s}$ of the regression model.

\section{$C_{p s} \mathrm{NO}_{3}^{-}$in catchment $i=\mathrm{C}_{m} \mathrm{NO}_{3}^{-}-C_{n p s} \mathrm{NO}_{3}^{-}$in catchment $i$}

where $C_{p s}$ represents the nitrate content attributable to point-source inputs to catchment area $i$, and $C_{m}$ indicates the measured nitrate concentration at the outlet of catchment area $i$.

Thus, the nitrate concentrations measured at the outlet of catchment area $i$ can be used to estimate the nitrate content attributable to point sources on the basis of the areal share of cropland in the catchment area:

\section{$C_{p s} \mathrm{NO}_{3}^{-}$in catchment $i=\mathrm{C}_{m} \mathrm{NO}_{3}^{-}-5.7+43.7 * P_{C L}$ in catchment $i$}

The regression model assumes a close correlation between concentrations and areal proportions of the land use types in the catchment area. If reliable runoff values are available at the outlet of the catchment area, they can also be used to quantify the components of the nitrate load, each of which originates from point and non-point sources.

\section{Pesticide contamination and nitrate levels}

Pesticides are another pollution factor that can impair the ecological quality of surface waters right at their source; therefore, water samples from 25 springs in the monitoring program that are characterized as predominantly agricultural were analyzed for pesticide content and the content of pesticide degradation products. The samples were collected in April, June and October of 2019. Among the sampled springs were three forest springs (percentage of agricultural land $<5 \%)$, which served as potentially uncontaminated reference sites (m01, b06).

A total of 26 pesticides and metabolites were detected. Atrazine, which has been banned in Germany since 1991 and in the EU since 2003, and its degradation product desethylatrazine were detected at four sites. However, the concentrations were below the limit values or orientation values of the surface water and drinking water ordinances. Worth noting is the detection of the neonicotinoid insecticide clothianidin at one spring (m08) during sampling in April 2019. As of February 2019, the application of this insecticide is no longer permitted. Atrazine was also detected at this site, and the spring exhibits the highest nitrate pollution of the entire study.

Fig. 7 shows the number of pesticidal agents detected along with the mean nitrate levels in 2018. A comparison of pesticide occurrences with nitrate contamination demonstrates a highly significant correlation between the number of detected substances and nitrate contamination $(r=0.77 ; p<0.01)$. The number of pesticides detected is also highly significantly positively correlated with the share of cropland $(r=0.64 ; p<0.01)$. In particular, the first relationship mentioned indicates a clear link between the intensity of conventional agricultural usage and water pollution. The absence of detected pesticides at sites $\mathrm{m03}$ and $\mathrm{k} 09$, which each have nitrate levels around $20 \mathrm{mg} / \mathrm{L}$ with an agricultural land share of $>85 \%$, confirms the influence of management practices on emissions. Grasslands predominate at k09, particularly in the immediate vicinity of the spring, while the cropland and grassland areas at $\mathrm{m} 03$ are managed according to the principles of organic farming.

\section{Discussion}

This study demonstrates that systematic monitoring of springs in settlement-free areas can be used to map the influence of land use on the pollutant level of surface water. Whereas soil moisture samples taken with the aid of 
lysimeters can only provide spatially limited data that are representative of the field from which they are collected, spring waters integrate the diverse uses throughout the catchment area.

\section{Interflow}

Due to its high degree of solubility, nitrate is discharged vertically into the groundwater via the soil moisture or laterally into the surface waters, if there is a sufficient slope. In the second case, as already described, the transport occurs as interflow in the near-surface groundwater flow within the upper soil horizons. The randomly performed piezometer tests demonstrate that, even with permeable bedrock, as with the Bunter sandstone, there is no clearly measurable descendant nitrate displacement. This indicates that nitrate discharges from agricultural land enter surface waters predominantly via interflow.

\section{Development of the nitrate content in the springs over two decades}

Most springs with agricultural catchment areas exhibit elevated nitrate levels. Depending on the area and intensity of cropland usage, annual average concentrations are near or above the EU-wide limit value of $50 \mathrm{mg} / \mathrm{L}$. These highly impacted springs exhibit a slight decrease during the three monitoring periods, 2002, 2011-12, and 2018, while many moderately impacted springs exhibit an increase to as high as $40 \mathrm{mg} / \mathrm{L}$. This seems to be due to the fact that official management targets only oblige farmers to implement measures to reduce nitrate emissions, if the limit value of the Nitrates Directive is repeatedly exceeded.

However, more or less constant nitrate concentrations of between 20 and $40 \mathrm{mg} / \mathrm{L}$ constitute a considerable pollution for watercourses and are far from the natural baseline level. The mean nitrate content of those springs in the study that were not impacted by agriculture is $3.6 \mathrm{mg} / \mathrm{L}$. Taking into account measurement inaccuracies due to the procedure, we can identify a threshold value of $5.6 \mathrm{mg} / \mathrm{L}$ of nitrate for the study area, above which agricultural impact can be assumed. Pollutant levels of up to $14.2 \mathrm{mg} / \mathrm{L}$ of nitrate are still tolerable from the point of view of marine ecology objectives. This value is still exceeded at 16 of the 22 agriculturally impacted springs in our 2018 study. At present, the marine ecology target value for official water pollution control is only regarded as a guideline. It is not applied in the German Surface Water Ordinance or in the current management plan for Saarland [11, 38]. The steadily increasing nitrate values of the springs with moderate pollution levels show that measures for reducing emissions are necessary even below the limit value of the Nitrates Directive. Watercourses that are already significantly contaminated in the area near the spring will receive additional point-source and non-point-source inputs further downstream. Because there is no significant nitrate retention in the upper reaches of the watercourse [29], and any dilution effect due to infiltration of interflow water is only to be expected when passing through longer, wooded sections or grassland zones, it can be assumed that the pollution level is at least constant along the entire length of the watercourse. The overall conclusion is that, despite major efforts by the authorities to protect bodies of water, nitrate inputs caused by agriculture have not been significantly reduced since the turn of the millennium. The reduced maximum values now observed at sites that previously had high pollution levels contrast with significantly increased nitrate levels at numerous other monitoring sites.

\section{Annual trend in nitrate content}

During all three monitoring periods, the nitrate content over the course of the year follows the seasonal interplay of discharge as a result of fertilization before and at the beginning of the growth phase, retention by the vegetation during the growth phase, and release after harvest as well as the decomposition of the dead biomass and 
subsequent flushing out during the autumn and winter months. The extreme hot, dry period during 2018 led to a stronger increase in nitrate concentrations during the winter than was observed in the other monitoring periods, particularly for soils with low water retention capacities. A considerable reservoir of nitrate accumulated in the soils during the long period of low-precipitation from late spring to autumn; this will be washed out at an accelerated rate by the onset of precipitation in autumn. This leads to nitrate concentrations rising significantly above the mean values after the autumn and winter rainfall events, thereby temporarily placing the aquatic ecosystems under additional stress. With an increasingly uneven distribution of precipitation over the course of the year, which is to be expected as climate change progresses $[19,40]$, an increase in the phases with peak levels in autumn/winter can also be assumed.

\section{Relationship between water pollution and agricultural land use}

The relationship between the nitrate content of the spring waters and the intensity of agricultural use was documented during all three monitoring periods. In each case, the share of cropland in the catchment area has a highly significant degree of correlation with the mean concentration, confirming the findings of other studies [17, 27 , 28].

A regression model that estimates the contribution of non-point-source inputs to the measured nitrate pollution at a given monitoring site for a watercourse can be derived based on this close correlation. The forecast model is based on a simple mass balance and assumes that nitrate retention is negligible along the flow path from the spring to the monitoring site at the catchment area outlet [29]. This assumption only applies to smaller bodies of water with at least moderate flow velocity. However, at larger river sections or very slow-flowing watercourses in lowland areas, discernible nitrate degradation processes are to be expected, which this model do not take into account. The most accurate estimates can be expected for catchment areas that correspond to the spring catchments studied here in terms of utilization mix and geo-ecological baseline situation. However, inaccuracies of greater or lesser magnitude are to be expected if, for example, large wetlands or emission-reducing forms of cultivation such as organic farming dominate in terms of area. This is also confirmed in studies by Li et al. (2021) and Casal et al. (2019), which demonstrated the effect of wetlands, unused buffer strips and grasslands that are mown several times per year in the vicinity of the upper reaches $[17,15]$. The significance is also limited for catchments with more settlement and infrastructure area than open spaces, because the share of non-point-source inputs as a cause of nitrate pollution is correspondingly lower.

In order to test the model further, mass balances should be drawn up in other areas at selected rural catchment areas using suitable modeling approaches, and monitoring sites should be set up at the catchment area outlets. By measuring nitrate and runoff over at least a one-year measurement period and by determining the areal proportions of cropland, meaningful data could be generated to validate the models.

The pesticide pollution of the springs is also related to the intensity of agricultural land use and shows a similar picture as the nitrate pollution: The detection of pesticidal agents exhibits a highly significant degree of correlation with nitrate concentrations. However, the detected pesticide levels were either zero or very low at some sites that are predominantly agricultural and have elevated nitrate levels. At these sites, local peculiarities of land use, such as grassland or wooded areas in the vicinity of the spring or organic farming on the majority of the cropland, are noticeable.

\section{Conclusion}


The overall conclusion from this study is that the systematic monitoring of spring waters can give a clear picture of the impact of agricultural usage in the catchment areas. The prerequisites are that the springs be located outside the influence of settlements and other potential emitters of pollutants and that the monitoring intervals in the campaign are monthly or shorter with monitoring being conducted over at least one full year. Given a sufficient number of representative catchment areas within a more or less geo-ecologically homogeneous region, it is possible to develop forecast models for determining non-point-source inputs to the surface waters of this region. This is the first time that it has been possible to quantify the impact of agriculture on small and medium-sized watercourses. The method can serve as an alternative or supplement to catchment-based modeling calculations. The approach can even be used in the context of official water monitoring, provided that the catchment areas are rural and do not deviate too much from the average situation in the study area in terms of topography, usage and geo-ecological baseline situation. Targeted, site-specific measures that contribute to improving the overall ecological status of the body of water can be derived for preventive water pollution control.

A comparison of the three monitoring periods over nearly two decades reveals that nitrate discharges from agricultural land have not decreased since the EC WFD entered into force. In the meantime, measures that have led to compliance with the limit value stipulated in the Nitrate Directive have been implemented at the sites that had exhibited extremely high levels of pollution in the past. Below this limit, however, nitrate levels have been increasing significantly in many cases since the first monitoring campaign. The marine ecology target value, which is to be understood as a point of reference for a nitrate pollution level that is still tolerable, is exceeded at numerous monitoring sites. In the future, this is where more official measures should be taken in order to permanently reduce nitrate inputs into surface waters from the land.

\section{Abbreviations}

WFD: Water Framework Directive; TN: Total Nitrogen; CEC: Cation Exchange Capacity; p: Precipitation; T:

Temperature; DWD: Deutscher Wetterdienst (German Weather Service); LVGL: Landesamt für Geoinformation und Landentwicklung (State Agency for Geoinformation and Rural Development); DGM: Digitales Geländemodell (Digital terrain model); ATKIS: Authoritative Topographic-Cartographic Information System; LUFA: Landwirtschaftliche Untersuchungs- und Forschungsanstalt (Agricultural Investigation and Research Institute); $\Delta \mathrm{T}$ : Temperature amplitude; EC: Electric conductivity;

\section{Declarations}

\section{Acknowledgements}

The authors would like to thank all persons and institutions who contributed to this study.

\section{Funding}

This research did not receive any specific grant from funding agencies in the public, commercial, or not-for-profit sectors.

\section{Authors' contributions}


GW planned, organized, supervised field and lab work and contributed to the conceptualization of the study. He conducted GIS-work, analysis of data, did the literature research and wrote the manuscript. JK was responsible for supervision and project administration as well as for conceptualization and study design in the initial phase of the study. All authors read and approved the final manuscript.

\section{Availability of data and material}

The datasets used and/or analyzed during the current study are available from the corresponding author on reasonable request.

\section{Ethics approval and consent to participate}

Not applicable.

\section{Consent for publication}

Not applicable.

\section{Competing interests}

The authors declare no financial and non-financial competing interests.

\section{Author details}

Saarland University, Physical Geography and Environmental Research, Am Markt Zeile 2, 66125 Saarbrücken, gero.weber@geo.uni-saarland.de

\section{References}

1. Kresic N, Stevanovic Z (2010) Groundwater hydrology of springs. Engineering, theory, management, and sustainability. Butterworth-Heinemann, Elsevier, Jordan Hill, Oxford.

2. Williams DD (1991) The spring as an interface between groundwater and lotic fauna and as a tool in assessing groundwater quality. Verh Internat Verein Limnol 24:1621-1624.

3. Katz BG, Chelette AR, Pratt TR (2004) Use of chemical and isotopic tracers to assess nitrate contamination and groundwater age, Woodville Karst Plain, USA. J Hydrol 289:36-61.

4. Tian S, Youssef MA, Richards RP, Liu J, Baker DB, Liu Y (2016) Different seasonality of nitrate export from an agricultural watershed and an urbanized watershed in Midwestern USA. J Hydrol 541:1375-1384.

5. Heathwaite AL (1993) Nitrogen Cycling in Surface Waters and Lakes. In: Burt TP, Heathwaite AL, Trudgill ST (eds). Nitrate: Process, Patterns and Management. Wiley, Chichester:99-140.

6. Carpenter SR, Caraco NF, Correll DL, Howarth RW, Sharpley AN, Smith VH (1998) Nonpoint pollution of surface waters with phosphorus and nitrogen. Ecol Appl 8 (3):559-568. http://dx.doi.org/10.2307/2641247. 
7. Strebel O, Duynisveld WHM, Böttcher J (1989) Nitrate Pollution of Groundwater in Western Europe. Agric Ecosyst Environ 26:189-214.

8. Yakovlev V, Vistivna Y, Diadin D, Vergeles Y (2015) Nitrates in springs and rivers of East Ukraine: Distribution, contamination and fluxes. Appl Geochemistry 53:71-78.

9. Kubiniok J, Neumann B, (1998) Stickstoffdynamik landwirtschaftlicher Kulturböden: Vergleich verschiedener Anbaumethoden und Möglichkeiten zur Ausweisung von Flächen unterschiedlichen

Nitratauswaschungspotentials. In: Saar-Lor-Lux, Umweltprobleme. Saarbrücker Geographische Arbeiten vol 44 pp 81-97.

10. EU WFD (2000) Directive 2000/60/EC of the European parliament and of the council of 23 October 2000 establishing a framework for community action in the field of water policy. Official Journal of European Union L327:1-72.

11. OGewV (2016) Verordnung zum Schutz der Oberflächengewässer (Oberflächengewässerverordnung - OgewV vom 20. Juni 2016). BGBI I p 1373

12. LAWA (2014) Empfehlung zur Übertragung flussbürtiger, meeres-ökologischer Reduzierungsziele ins Binnenland. Bund/Länderarbeitsgemeinschaft Wasser (ed), Dresden.

13. Trepel M, Fischer M (2014) Übertragung meeresökologischer Reduzierungsziele ins Binnenland. Wasser und Abfall 9:34-37.

14. Cheng X, Chen L, Sun R (2019) Modeling the non-point source pollution risks by combing pollutant sources, precipitation, and landscape structure. Environ Sci Pollut Res. 26:11856-11863.

15. Casal L, Durand P, Akkal-Corfini N, Benhamou C, Laurent F, SImon-Monviola J, Ferrant S, Probst A, Probst J-L, Vertés F (2019) Reduction of stream nitrate concentrations by land management in contrasted landscapes. Nutr Cycl Agroecosyst 114:1-17. https://doi.org/10.1007/s10705-019-09985-0.

16. Richards G, Gilmore TE, Mittelstet AR, Messer TL, Snow DD (2021) Baseflow nitrate dynamics within nested watersheds of an agricultural stream in Nebraska, USA. Agric Ecosyst Environ 308, 107223. https://doi.org/10.1016/j.agee.2020.107223.

17. Li Y, Boswell E, Thompson A (2021) Correlations between land use and stream nitrate-nitrite concentrations in the Yahara River Watershed in south-central Wisconsin. J Environ Manage vol 278, Part 2, 111535. https://doi.org/10.1016/j.jenvman.2020.111535.

18. Goeller BC, Febria CM, Warburton HJ, Hogsden KL, Collins KE, Devlin HS, Harding JS, Mclntosh AR, (2019) Springs drive downstream nitrate export from artificially-drained agricultural headwater catchments. Sci Total Environ vol 671:119-128. https://doi.org/10.1016/j.scitotenv.2019.03.308.

19. Burg A, Heaton THE (1998) The relationship between the nitrate concentration and hydrology of a small chalk spring, Israel J Hydrol 204:68-82.

20. Katz BG (2004) Sources of nitrate contamination and age of water in large karstic springs of Florida. Environ Geol 46:689-706.

21. Katz BG, Böhlke JK, Hornsby HD (2001) Timescales for nitrate contamination of spring waters, northern Florida, USA. Chem Geol 179: 167-86.

22. Leibundgut C (1998) Tracer-based assessment of vulnerability in mountainous headwaters. In: Kovar K, Tappeiner U, Peters NE, Craig RG (eds) Hydrology, water resources and ecology in headwaters (proceedings of the HeadWater '98, Merano, Italy), 248. IAHS Publ. pp 317-325. 
23. Panno SV, Hacley KC, Hwang HH, Kelly WR (2001) Determination of the sources of nitrate contamination in karst springs using isotopic and chemical indicators. Chem Geol 179:113-128.

24. Amiel RB, Grodek T, Frumkin A (2010) Characterization of the hydrogeology of the sacred Gihon Spring, Jerusalem: a deteriorating urban karst spring. Hydrogeol J 18:1465-1479.

25. Boy-Roura M, Mencio A, Mas-Pla J (2013) Temporal analysis of spring water data to assess nitrate inputs in groundwater in an agricultural area (Osona NE Spain). Sci Total Environ 452-453:433-445.

26. Menció A, Boy M, Mas-Pla J (2011) Analysis of vulnerability factors that control nitrate occurrence in natural springs (Osona region, NE Spain). Sci Total Environ, 409:3049-3058.

27. Weber G, Kubiniok J (2013) Investigation of spring waters to assess the geo-ecological state of landscape and soil. J Agric Sci Technol A 3:592-602.

28. Kubiniok J, Feltes W, Neumann B, Bruch I (2004) Diffuse und punktuelle Stickstoffeinträge in Quellen und Oberläufe kleiner saarländischer Fließgewässer. In: VDLUFA-Schriftenreihe 59, Kongressband 2003, Saarbrücken, pp 685-692.

29. Weber G, Honecker U, Kubiniok J (2020) Nitrate dynamics in springs and headwater streams with agricultural catchments in southwestern Germany. Sci Total Environ vol 722:137858.

30. Liedtke H, Marcinek J (2002) Physical Geography of Germany, Gotha and Stuttgart.

31. DWD (2019) Vieljährige Mittelwerte, Deutscher Wetterdienst (ed.), URL: https://www.dwd.de/DE/leistungen/klimadatendeutschland/vielj_mittelwerte.html. Accessed 07 July 2021.

32. AdV (2018) Authorative Topographic-Cartographic Information System (ATKIS). http://www.adv-online.de. Accessed 07 July 2021.

33. DEV (1979) Deutsches Einheitsverfahren zur Wasser-, Abwasser- und Schlammuntersuchung. DIN 38405. Band 2, Teil 9, Anionen (Gruppe D). Berlin, Wien, Zürich.

34. DEV (1995) Deutsche Einheitsverfahren zur Wasser-, Abwasser- und Schlammuntersuchung - Anionen (Gruppe D),Teil 29: Photometrische Bestimmung von Nitrat mit Sulfosalizylsäure (D 29). DIN 38405-29:1994-11. ISO 7890-3:1988, modifiziert. Berlin, Wien, Zürich.

35. DEV (1983) Deutsches Einheitsverfahren zur Wasser-, Abwasser- und Schlammuntersuchung. DIN 48406. Band 3, Teil 5, Kationen (Gruppe E). Berlin, Wien, Zürich.

36. Weber G, Christmann C, Thiery A-C, Martens D, KubiniokJ (2018) Pesticides in agricultural headwater streams in southwestern Germany and effects on macroinvertebrate populations. Sci Total Environ vol 619-620:638-648, ISSN 0048-9697, doi.org/10.1016/j.scitotenv.2017.11.155

37. DIN (2014) German standard methods for the examination of water, waste water and sludge - Jointly determinable substances (group F) - Part 36: Determination of selected active substances of plant protection products and other organic substances in water - Method using high performance liquid chromatography and mass spectrometric detection (HPLC-MS/MS or -HRMS) after direct injection (F 36).

38. MUV (2020) 3. Bewirtschaftungsplan nach Artikel 13 der Richtlinie 25000/60/EG des Europäischen Parlaments und des Rates vom 23. Oktober 2000 für das Saarland, URL:

https://www.saarland.de/SharedDocs/Downloads/DE/muv/wasser/WRRL/3bewirtschaftungsplan. Accessed 22 July 2021.

39. Held IM, Soden BJ (2006) Robust responses of the hydrological cycle to global warming. J Climate 19:56865699. 
40. Brasseur G, Jacob D, Schuck-Zöller S (eds) (2017) Klimawandel in Deutschland - Entwicklung, Folgen, Risiken und Perspektiven. Springer Spektrum, Berlin/Heidelberg.

\section{Figures}

Figure 1

Location of the sampling sites in the main geological units of Saarland (dots = springs; circles = piezometers)

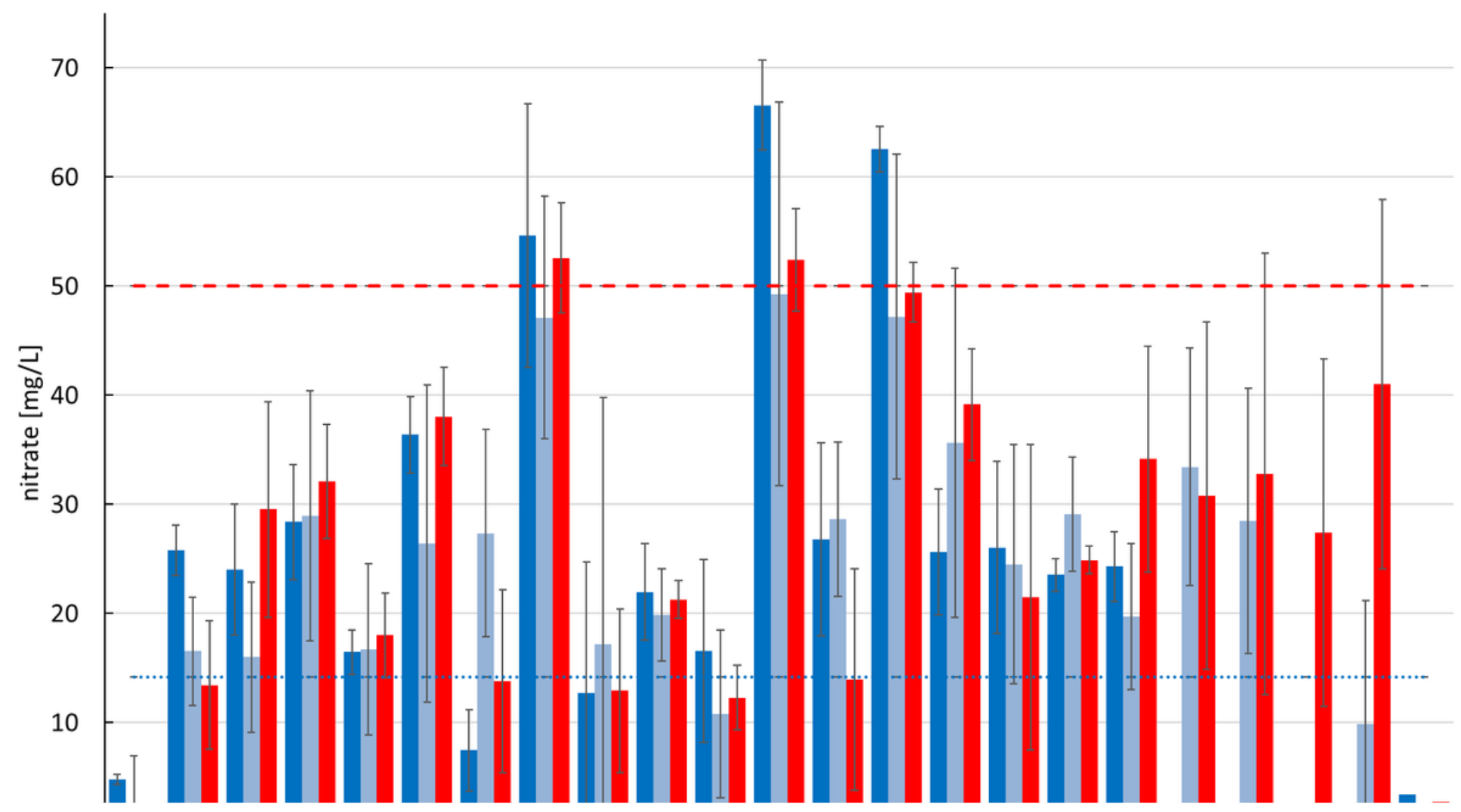

Figure 2

Nitrate content of 22 springs influenced by agriculture (median and standard deviation of 12 monthly measurements) and average of all forest springs; comparison of three measurement periods (dark blue = 2002; light blue = 2011-12; red = 2018; dotted line = target value $14.2 \mathrm{mg} / \mathrm{L}$; dotted line $=$ Nitrate Directive threshold $50 \mathrm{mg} / \mathrm{L}$ ) 


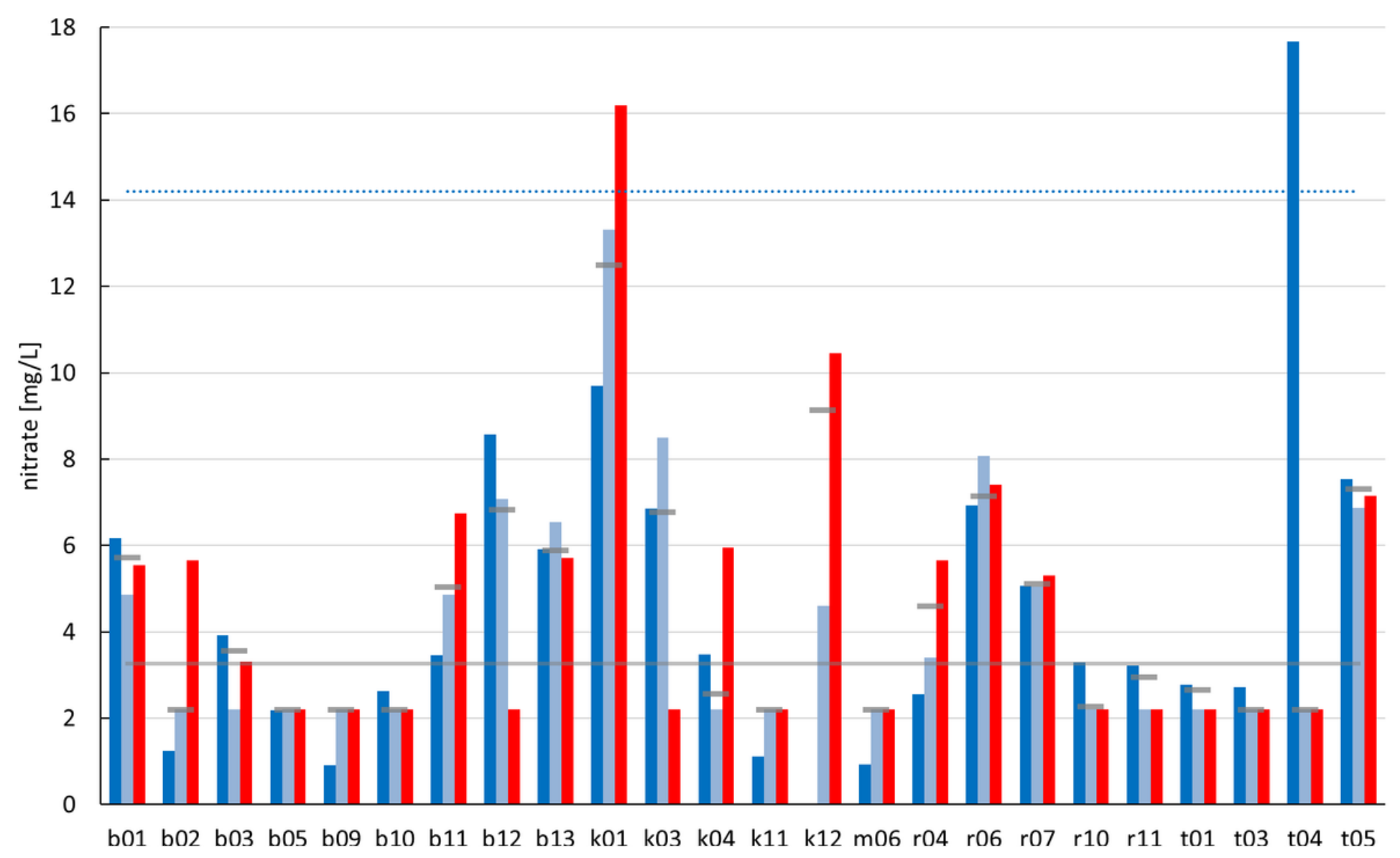

\section{Figure 3}

Nitrate content of springs outside agricultural influence (farmland $<1 \%$ ); median of 12 monthly measurements (dark blue = 2002; light blue $=2011-12 ;$ red $=2018 ;$ dotted line $=$ target value $14.2 \mathrm{mg} / \mathrm{L}$; short gray lines = median of 3 periods; gray line = median of all values)

Figure 4

Nitrate content during the course of the year for two exemplary springs with monthly precipitation $\mathrm{p}$

Figure 5

Correlation of nitrate content and share of cropland (A) and grassland (B) in catchment areas of 55 springs in the 2018 monitoring period.

Figure 6 
Correlation of nitrate content (median) and share of cropland in the catchment areas of 50 springs for three monitoring periods (circles $/$ solid line $=2018, x /$ dotted line $=2011-12,+/$ dashed line $=2002$ ) .

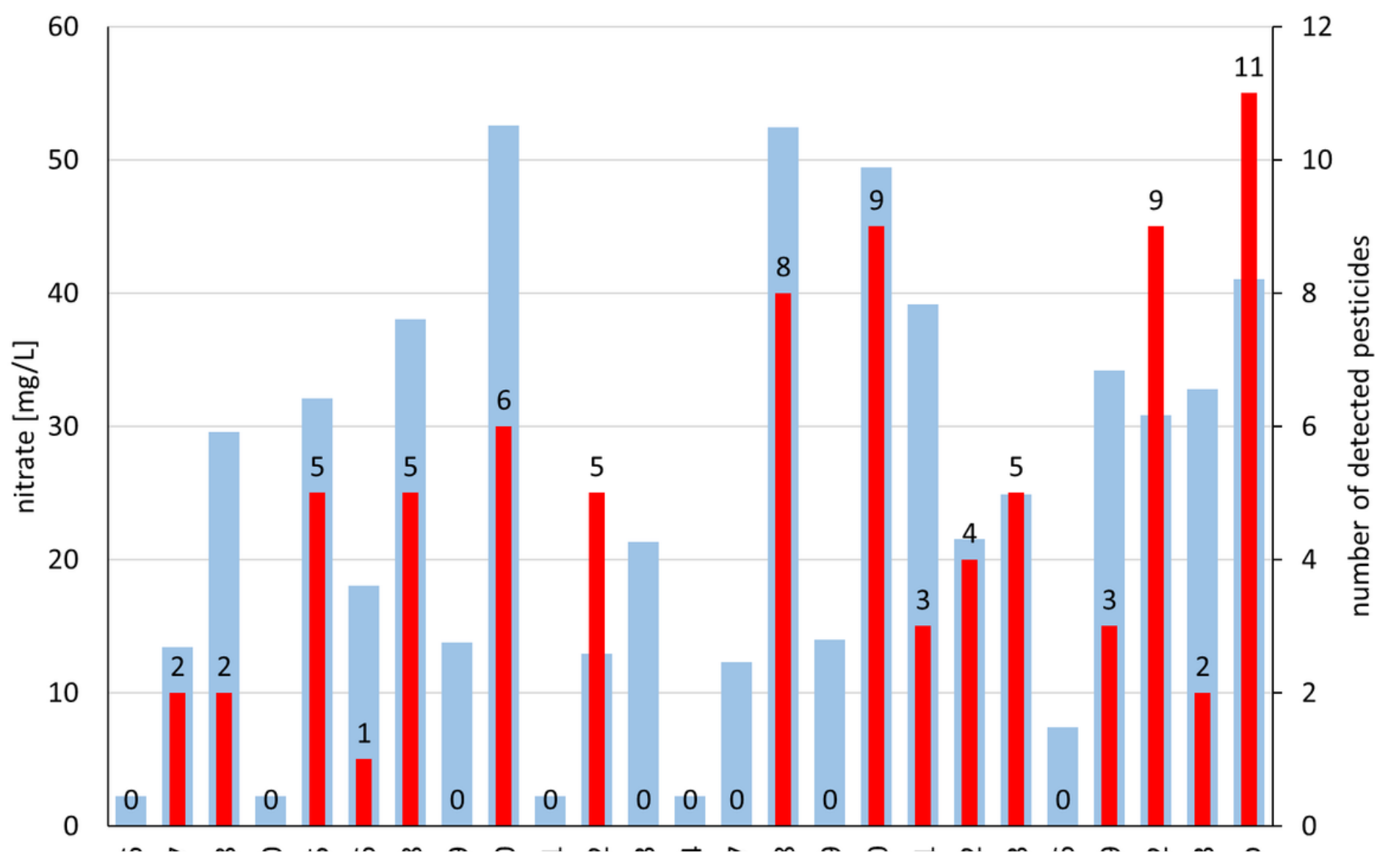

\section{Figure 7}

2018 concentrations of nitrate and pesticides (including transformation products) in selected springs 2019 (blue = nitrate median of 12 monthly measurements; red = number of detected pesticides) 